DOI:

\title{
A rare cause of chronic knee effusion: Lipoma arborescens
}

\author{
Kronik diz effüzyonunun nadir bir sebebi: Lipoma arborescens
}

Samet Sancar KAYA, Yakup ERDEN

\begin{abstract}
Lipoma arborescens (LA) is a rare intra-articular benign lesion commonly found in the knee. LA presents with chronic painless swelling. Diagnosis is easily done by specific signs of LA on magnetic resonance imaging (MRI). Typically, LA is treated by open or arthroscopic synovectomy. A 30-year-old male patient was admitted with swelling in his right knee. He had chronic swelling of the suprapatellar bursa with recurrent episodes of effusion in his right knee for 1 year. He was diagnosed with LA by monitoring synovial villous proliferations that signal isointense with adipose tissue in all sequences on MRI. LA is a disease that should be remembered in patients with recurrent effusions in the knee joint. MRI plays an important role in diagnosis.
\end{abstract}

Keywords: Lipoma arborescens, Synovial hyperplasia, Intraarticular lipoma

Samet Sancar Kaya $(\varangle)$

Physical Medicine and Rehabilitation Clinic, Patnos State Hospital, Ağrl, Turkey

e-mail: sametsancarkaya@hotmail.com

Yakup Erden

Physical Medicine and Rehabilitation Clinic, Duzce Ataturk State Hospital, Duzce, Turkey

Submitted / Gönderilme: 08.08.2017

Accepted/Kabul: 03.09.2017

\section{ÖZET}

Lipoma arboresens (LA) genellikle dizde görülen nadir bir intraartiküler benign lezyondur. LA, kronik ve ağrısız şişlik ile presente olur. Tanı, manyetik resonans görüntülemede (MRG) LA'ya ait spesifik görüntülerin izlenmesi ile kolaylıkla konulur. Tedavisi sinoviyektomidir. Bu yazımızda, 30 yaşında sağ dizde LA tanısı konulan bir hasta sunuldu. Hastanın 1 yıldır sağ dizinde tekrarlayan effüzyon atakları ile birlikte suprapatellar poşta kronik şişliği vardı. MRG'de tüm sekanslarda yă̆ doku ile izointens sinyal veren sinoviyal villöz proliferasyonların izlenmesi ile hastaya LA tanısı konuldu. LA kronik diz effüzyonlu hastaların ayırıcı tanısında akılda tutulmalıdır.

Anahtar kelimeler: Lipoma arboresens, Sinoviyal hiperplazi, Eklem içi lipom

\section{Introduction}

Lipoma arborescens (LA) is a rare intra-articular benign lesion characterized by lipomatous villous proliferation in synovium, usually seen in adults. The most common site of occurrence is suprapatellar pouch. It rarely can be seen in the hip, shoulder and elbow joints [1]. Although, the etiology is not completely known, chronic synovial irritation, meniscus injuries, trauma, rheumatoid arthritis and diabetes are blamed for LA [1,2]. Clinically, chronic painless swellings due to recurrent episodes of effusion is usually seen in LA. Laboratory tests and evaluation of joint aspiration results are in the normal rage. Magnetic resonance imaging (MRI) is the gold standard for the diagnosis of LA [3]. In treatment, open or arthroscopic synovectomy is recommended $[3,4]$.

In this paper, a 30-year-old patient with LA diagnosis in the right knee was presented and current information about the subject was discussed. 


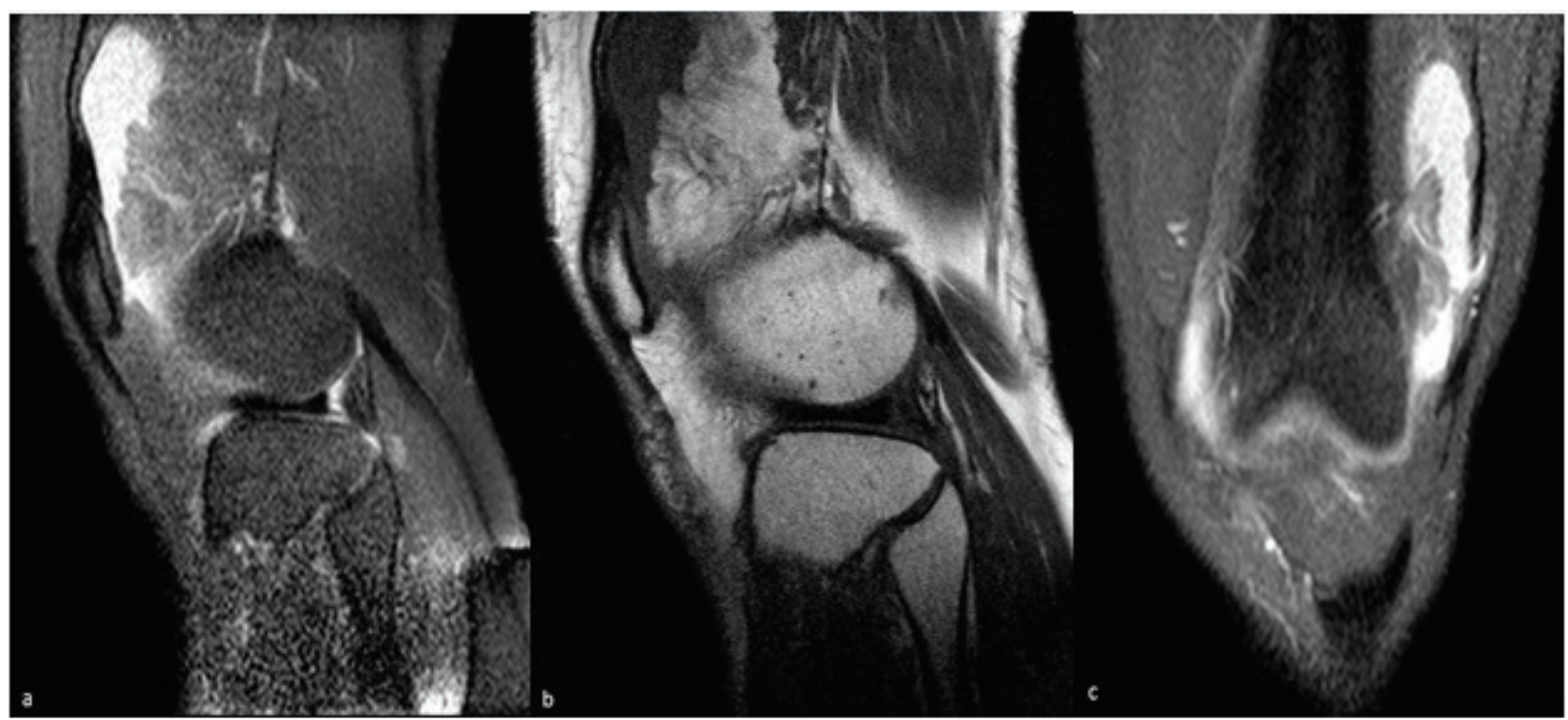

Figure 1. MRI images of the right knee. (a) $T_{1}$ weighted sagittal image showing (a) the frond-like villous lipomatous proliferation in the suprapatellar bursa $(\mathrm{b}, \mathrm{c})$ Fat suppressed $T_{2}$ weighted sagittal and coronal image showing decreased signal intensity of lipomatous proliferation

\section{Case Report}

A 30-year-old male patient was admitted to our outpatient clinic with pain, swelling and limited motion for 1 year in his right knee. Swelling and limitation of movement of the patient's right knee increased periodically. Non-steroidal anti-inflammatory drugs were given to the patient for these complaints, but the complaints did not improve. Examination reveals suprapatellar swelling and tenderness in his right knee. Knee joint movements were limited and there was no warmth or redness around the knee. McMurray, Apley and knee stabilization tests were within the normal rage.

Erythrocyte sedimentation rate, hemogram, C-reactive protein (CRP), rheumatoid factor (RF), anti-streptolysin-O (ASO) and biochemical parameters were within normal limits. Laboratory tests and microscopic investigations of the knee joint fluid were all within normal rage. Aspirated synovial fluid culture was negative. X-ray of the knee revealed soft tissue expansion. In MRI, hyperintense synovial thickening was observed on $\mathrm{T} 1$ and $\mathrm{T} 2$-weighted sequences and complete suppression of villous structures was observed in fat-printed sequences. Meniscus or ligamentous lesions were not observed. Based on all these findings, the patient was diagnosed with primary type LA and the patient was referred to the orthopedic clinic for surgical synovectomy.

\section{Discussion}

Lipoma arborescens is a rare benign intra articular lesion characterized by lipomatous villous proliferation in the subsynovial tissue, secondary to adipocyte hypertrophy. LA rarely affects other anatomical regions except the knee. Wolf et al. for the first time described a patient with LA in the hip [5]. Mohammad et al. reported LA in bicipitoradial bursae of the elbow [6].

LA is often seen in men aged 30 to 50 years, although it has also been reported in children. Aydin et al. reported two sisters with LA aged 9 and 15 years [7].

Its etiology is not clear. Histopathologic studies have shown that mature fat cells replace the subsinovyal tissue, chronic mononuclear cell infiltration in synovial layer and lipomatous villous proliferation in synovium.

It is claimed that LA has two types, primary and secondary. Primary type LA is seen as idiopathic in the first 3 decades, independent of joint degeneration. Secondary type, the more common type of LA is thought to be reactive development to osteoarthritis, chronic irritation, synovitis, meniscus injuries, rheumatoid arthritis and diabetes [8]. In a study, LA and related lesions were investigated by MRI, all of the LA patients had joint effusion. Eighty-seven percent degenerative changes, $72 \%$ meniscus damage, $38 \%$ synovial 
cysts, $25 \%$ bone erosions and $13 \%$ synovial chondromatosis were detected [9].

Patients are presented with the chronic painless swelling due to recurrent effusion. Pain can also occur during episodes of effusion. Hemogram, sedimentation, CRP, uric acid levels and serological tests are usually normal. No crystals are observed in the joint aspiration, fluid cell count is normal and culture is negative. Plain radiograph may reveal focal radiolucent areas in the joint and suprapatellar bursa due to fatty tissue. Ultrasonography can detect effusion and hyperechoic villous hypertrophic structures. MRI is the gold standard for the diagnosis of LA [3,8]. In MRI, fround-like hyperintense villous synovial proliferations in all sequences and complete suppression of these villous structures in fatprinted sequences are observed.

Synovial osteochondromatosis, pigmented villonodular synovitis (PVNS), synovial hemangiomatosis and rheumatoid nodule can be considered in the distinctive diagnosis of LA. Synovial lipoma has a well-circumscribed mass with fatty consistency. PVNS displays hypointense appearance in all pulse sequences due to accumulation of hemosiderin. Synovial chondromatosis also has a hypo / isointense appearance in T1- and T2-weighted sequences and loose bodi are observed in the joint. T2 weighted sequences give a high signal while $\mathrm{T} 1$ weighted sequences give medium signal in synovial hemangioma. T2 weighted sequences give a low signal while T1 weighted sequences give medium signal in rheumatoid nodule. These findings help in differentiating the LA from other conditions. [1012]. Open or arthroscopic synoviectomy is recommended for LA treatment and relapse after synoviectomy does not usually develop [4]. An LA patient treated with Yttrium-90 has also been reported [13].

In this case the patient is a typical primary type LA patient regarding age and MR imaging findings. In patients with LA pain usually does not coincide with knee effusion but in our case the patient had pain and tenderness when swelling occurred. Some reporters suggested that there is an association between lipoma arborescens and degenerative joint disease, however, our patient was young and degenerative changes and meniscus tears were not observed on MRI.
As a result, LA should be included in the differential diagnosis of the patients with recurrent painless effusions in patients without systemic symptoms and distinctive diagnosis must be performed by MRI.

Conflict of Interest: No conflict of interest was declared by the authors.

\section{References}

1. Ryu KN, Jaovisidha S, Schweitzer M, Motta A O, Resnick D. MR imaging of lipoma arborescens of the knee joint. AJR 1996;167:1229-32. doi: 10.2214/ajr.167.5.8911186

2. Kloen P, Keel SB, Chandler HP, et al. Lipoma arborescens of the knee. J Bone Joint Surg Br 1998;80:298-301.

3. Patil PB, Kamalapur MG, Joshi SK, Dasar SK, Rao RV. Lipoma arborescens of knee joint: role of imaging. J Radiol Case Rep 2011; 5: 17-25. doi: 10.3941/jrcr.v5i11.783.

4. Feller J, Rishi M, Hughes E. Lipoma arborescens of the knee: MR demonstration. AJR Am J Roentgenol 1994;163:162-4. doi: 10.2214/ajr.163.1.8010204

5. Wolf RS, Zoys GN, Saldivar VA, et al. Lipoma arborescens of the hip. J Rheumatol 2002; 29 (5) : 1088-92.

6. Mohammad HR, Chaturvedi, A, Peach C. An unusual case of lipoma arborescens. The Annals of The Royal College of Surgeons of England, 2016, 98.7: 126-129.

7. Aydın G, Keleş I, Tosun Ö, et al. Lipoma arborescens in childhood: a report of two sisters. Archives of Rheumatology, 2012, 27.1: 056-062.

8. Yah CH, Wong JWK, Yip DKH. Bilateral knee lipoma arborescens: A case report. J Orthop Surg 2008;16:107-10. doi: 10.1177/230949900801600125

9. Vilanova JC, Barcelo J, Villalon M, et al. MR imaging of lipoma arborescens and the associated lesions. Skeletal Radiology 2003; 32:504-9. doi: 10.1007/s00256-003-0654-9

10. Sheldon PJ, Forrester DM, Learch TJ. Imaging of intraarticular masses. Radiographics 2005; 25: 105-19. doi: 10.1148/rg.251045050

11. Plotkin BE, Varma R. Lipoma Arborescens of the Knee in a 17 - year old man. Radiology Case Reports. 2008;3:01-05. doi: $10.2484 /$ rcr.v3i2.164

12. Murphey MD, Carroll JF, Flemming DJ, et al. Benign musculoskeletal lipomatous lesions1. Radiographics 2004; 24: 1433-66. doi: 10.1148/rg.245045120

13. Erselcan T, Bulut O, Bulut S, et al. Lipoma arborescens; succesfully treated by yttrium-90 radiosynovectomy. Annals Nucl Med 2003; 17: 593-6. 